\title{
24 \\ CLIMATE CHANGE, ROSS RIVER VIRUS AND BIODIVERSITY
}

\author{
PHILIP WEINSTEIN AND PENG BI
}

\begin{abstract}
Infection with the Australian Ross River virus (RRV) results in rash, fever and rheumatic symptoms lasting several weeks, with epidemics strongly influenced by climatic variables that impact mosquito biology. The disease can be contextualised in terms of broader issues of resource overutilisation that leads to the degradation of ecosystems, with biodiversity loss potentially contributing to the emergence of the disease. The possible ecological linkage mechanisms between biodiversity loss and RRV infection are discussed and research needs in the area are highlighted.
\end{abstract}

\section{Background}

Tony McMichael's 1993 book, Planetary Overload, introduced ecological approaches to public health researchers and epidemiologists. The concept of carrying capacity was presented in such a way as to make many of these researchers rethink their approaches to a variety of pathogens, including RRV.

\section{Ross River Virus}

This Australian arbovirus (arthropod-borne virus) causes symptomatic infection in up to 5,000 people per annum, resulting in rash, fever and rheumatic symptoms lasting several weeks. Epidemics were first described in the late 1920s (Nimmo, 1928), and the ecology and distribution of RRV is now known to be determined by climatic variables that impact mosquito biology, including temperature and rainfall (for a review, see Russell, 2002). 
Until Planetary Overload (McMichael, 1993), the ecology of RRV and other vector-borne diseases had not been contextualised in terms of the broader issues of resource overutilisation that leads to the degradation of ecosystems. Anthropogenic climate change is prominent among the 'ecosystem services' (sensu Millennium Ecosystem Assessment, 2005) that are lost when resource utilisation exceeds carrying capacity, and several of McMichael's students and colleagues studied the relationships between climate and RRV (e.g. Tong et al., 1998; McMichael et al., 2003).

The ecological context of RRV transmission has been considered(Weinstein, 1997; Jardine et al., 2011), and the disease has been used to illustrate the importance of responding to the research challenges presented by the Millennium Ecosystem Assessment (MEA) (Weinstein, 2005). The MEA highlighted the significant loss in biodiversity that has resulted from 'planetary overload' and, importantly, ties adverse human health outcomes to that loss.

We suggest that the relationship between climate change, RRV and biodiversity loss remains under-researched and now should be prioritised. Carver et al. (2010) describe the role of biodiversity (predators and competitors) in suppressing the potential dominance of an RRV vector mosquito in an area in Western Australia affected by both decreasing rainfall and deforestation. In the study area, the combined effects of climate change and biodiversity loss may be synergistic because rainfall is inadequate to wash away saline surface water; residual brackish water pools then provide habitat for the salt-tolerant vector, Aedes camptorhynchus, which survives there better than do its competitors. Consequently, the 'emergence' of RRV infection is potentially facilitated. An additional layer of complexity is added to this analysis if one takes into account the populations of natural reservoir hosts for RRV, which may also be affected adversely by climate change. In other systems, a loss of potential host biodiversity has been shown to enhance disease transmission (Ostfeld and Keesing, 2000), perhaps because the 'dilution effect' provided by poorer reservoir species is lost. Conversely, a biologically sterile environment provides little opportunity for vector-borne disease transmission, but is hardly an attractive alternative. The possible relationship between climate change and reservoir biodiversity remains unstudied for RRV and, clearly, together with land use, has the potential to affect the future disease burden.

Other mechanisms by which climate change and biodiversity loss could interact to affect vector mosquitoes and disease ecology include changed water temperature and nutrient depletion in standing water ( $\mathrm{O}^{\prime}$ Reilly et al., 2003); seasonality and phenological disruption between predators and prey (Saino et al., 2011); and, the frequency and intensity of extreme weather events affecting species composition (Willig and Walker, 1999). 


\section{Conclusions Relating to Ross River Virus as a Model}

Ross River virus may provide a case study for climate change and biodiversity loss interactions and effects on vector-borne disease (Figure 24.1). In keeping with the thrust of Planetary Overload, such research would ideally lead to recommendations for interventions that provide benefits for both a healthy ecosystem and healthy human populations concurrently.

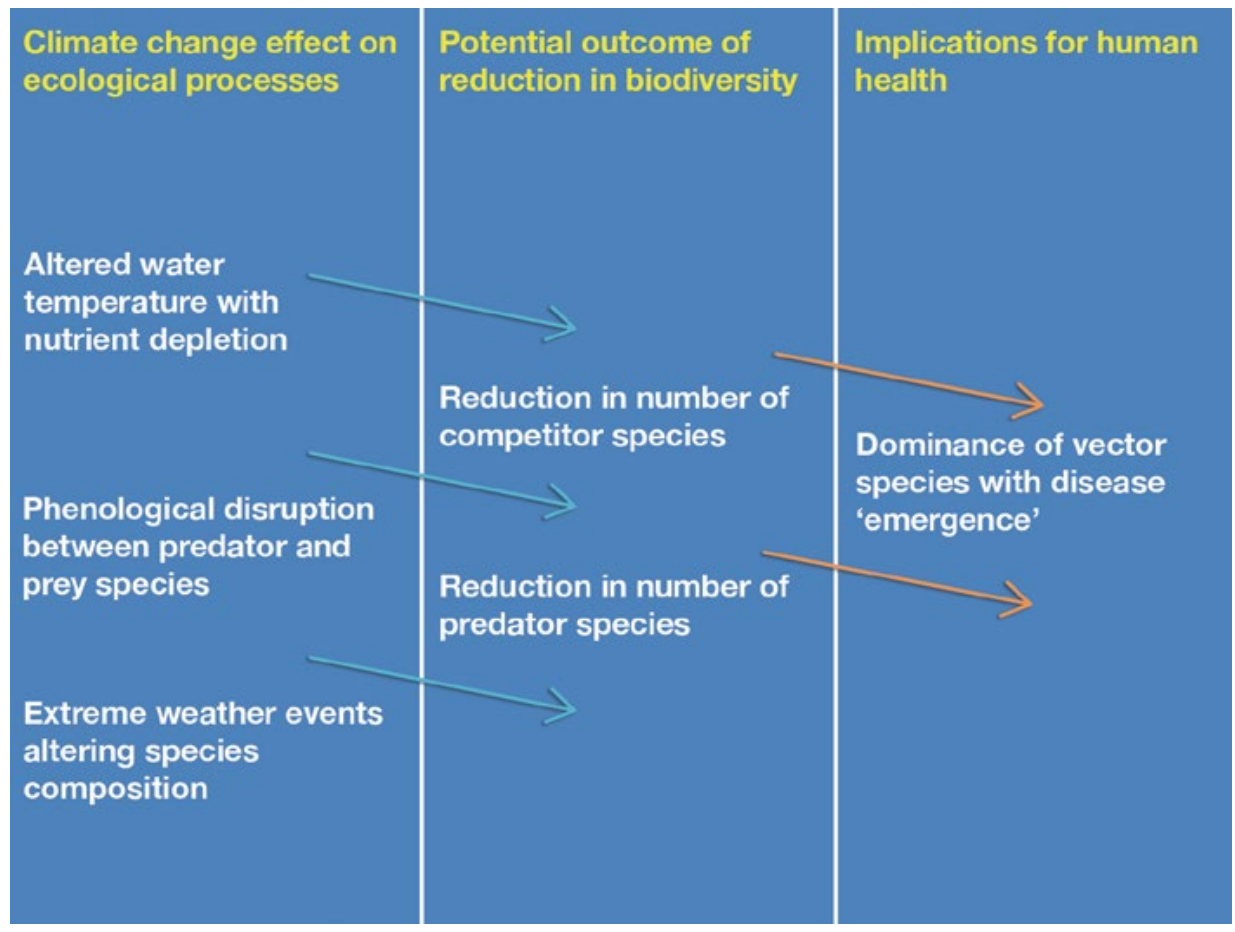

Figure 24.1 Potential relationships between climate change, biodiversity loss and the 'emergence' of vector-borne disease problems.

Source: Authors' work.

\section{Acknowledgements}

We thank an anonymous reviewer for helpful comments and Scott Carver for earlier discussions. 


\section{References}

Carver, S., Spafford, H., Storey, A. \& Weinstein, P. 2010. The roles of predators, competitors, and secondary salinisation in structuring mosquito (Diptera: Culicidae) assemblages in ephemeral water bodies of the wheatbelt of Western Australia. Environmental Entomology 39, 798-810.

Jardine, A., Corkeron, M. \& Weinstein, P. 2011. Dryland salinity and vectorborne disease emergence in southwestern Australia. Environmental Geochemistry and Health 33, 363-70.

McMichael, A.J. 1993. Planetary Overload. Global Environmental Change and the Health of the Human Species. Cambridge University Press, Cambridge, UK.

McMichael, A.J., Woodruff, R.E., Whetton, P., Hennessy, K., Nicholls, N., Hales, S., et al. 2003. Human Health and Climate Change in Oceania: A Risk Assessment. Commonwealth Government, Canberra, Australia.

Millennium Ecosystem Assessment 2005. Synthesis Reports. Available at: www.maweb.org/en/Reports.aspx, accessed 30 January 2015.

Nimmo, J.R. 1928. An unusual epidemic. Medical Journal of Australia i, 549-50.

O'Reilly, C.M., Alin, S.R., Plisnier, P.-D., Cohen, A.S. \& McKee, B.A. 2003. Climate change decreases aquatic ecosystem productivity of Lake Tanganyika, Africa. Nature 424, 766-8.

Ostfeld, R.S. \& Keesing, F. 2000. The function of biodiversity in the ecology of vector-borne zoonotic disease. Canadian Journal of Zoology 78, 2061-78.

Russell, R.C. 2002. Ross River virus: ecology and distribution. Annual Review of Entomology 47, 1-31.

Saino, N., Ambrosini, R., Rubolini, D., von Hardenberg, J., Provenzale, A., Hüppop, K., et al. 2011. Climate warming, ecological mismatch at arrival and population decline in migratory birds. Proceedings of the Royal Society B: Biological Sciences 278, 835-42.

Tong, S., Bi, P., Parton, K., Hobbs, J. \& McMichael, A.J. 1998. Climate variability and transmission of epidemic polyarthritis. The Lancet 351, 1100.

Weinstein, P. 1997. An ecological approach to public health intervention: Ross River virus in Australia. Environmental Health Perspectives 105, 364-6. 
Weinstein, P. 2005. Human health is harmed by ecosystem degradation, but does intervention improve it? A research challenge from the Millennium Ecosystem Assessment. EcoHealth 2, 228-30.

Willig, M.R. \& Walker, L.R. 1999. Disturbance in terrestrial ecosystems: salient themes, synthesis, and future directions. In: Walker, L.R. (ed.) Ecosystems of Disturbed Ground. Elsevier Science, Amsterdam, The Netherlands, 747-67. 
This text is taken from Health of People, Places And Planet:

Reflections based on Tony McMichael's four decades of contribution to epidemiological understanding, edited by Colin D. Butler, Jane Dixon and Anthony G. Capon, published 2015 by ANU Press, The Australian National University, Canberra, Australia. 